\title{
Polisin Özerkliği: Polis ve Siyaset İliş̧kisini Yeniden İncelemek
}

\author{
Police Autonomy: Reexamination of the Relationship between Politics \\ and the Police
}

Ayfer Genç YILMAZ ${ }^{*}$

\section{Öz}

Dünya genelinde modern devlet oluşum süreçleriyle eş zamanlı biçimde ulusal polis teşkilatlarının kurulmasıyla birlikte polislik de siyasal alana hızla dahil olmuştur. Bu durum polis ve siyaset arasındaki ilişkiyi daha fazla görünür hale getirmiştir. Ancak siyaset ve polis arasındaki ilişki Türkiyéde polis çalışmalarıyla ilgilenen sosyal bilimciler tarafından yok denecek kadar az sayıda incelemenin konusu edilmiştir. Elinizdeki çalışma işte bu teorik boşluğu doldurmak amacıyla polis-siyaset ilişkisine dair ana yaklaşımları ele almakta ve eleştirel bir süzgeçten geçirmektedir. Bu doğrultuda, makale kapsamında polis ve siyaset arasındaki ilişkinin nasıl çalışılması gerektiğine dair bir analitik temel ortaya konulmak istenmektedir.

Polis-siyaset arasındaki ilişkiyi incelemeye yönelik başlıca yaklaşımlardaki farklılıklar her şeyden önce bu yaklaşımların polisin nasıl tanımlandığına ilişkin farklı bakış açılarından kaynaklanmaktadır. İlk olarak, polisi bir kurum olarak ele alan yaklaşımlar ağırlıkla polis-siyasal iktidar ilişkisine odaklanmaktadır. Bu yaklaşıma göre polis siyasal iktidarın elinde bir araç olarak belirir ve siyasal iktidarı elinde bulunduran hükümetin doğrudan denetimi altında görev yapar. Dolayısıyla polis teşkilatı özerk değildir. İkinci olarak polisi polislik işlevine referansla tanımlayan yaklaşımlar polisliğin siyasete etki etme biçimleri üzerinde durmaktadır. Buna göre polislik siyasal süreçler tarafından belirlendiği gibi onları belirleme yetkisi ve becerisine de sahiptir. Burada, polisliğin siyasal süreçlere aktif müdahalesi ön plandadır. Elinizdeki çalışma ise söz konusu teorik yaklaşımların mirasını ve katkısını reddetmemekle birlikte polis-siyaset ilişkisine dair geliştirilecek bir teoriye polisin özerkliği meselesinin de mutlaka dâhil edilmesi gerektiği görüşündedir. Buna göre polisin mikro ve makro düzeyde yararlandığı özerklik polisin siyaset ile olan ilişkisini de büyük ölçüde belirlemektedir. Profesyonel merkezi örgütlenmeler olarak kendi kimlik ve haklarını savunmaya muktedir kurumlar olarak karşımıza çıkan polis teşkilatları kurumsal ve polis memurları da bireysel özerklikten yararlanırlar. Ancak bu özerkliğin sınırları vardır. Göreli özerklik kavramı da tam da bu noktada polis araştırmalarına dahil edilmelidir. Polisin özerkliğinin göreli karakteri ise polis-siyaset ilişkisine dair genel-geçer teorilerin uygulanması yerine tarihsel ve toplumsal bağlama yerleşecek dinamik ilişkiselliklerin olgusal düzeyde gözlemlenmesi ihtiyacını ortaya çıkarmaktadır.

Anahtar Kelimeler: Polis, Polislik, Siyaset, Özerklik, Meşruiyet

\footnotetext{
* Bu çalışma, yazarın Yıldız Teknik Üniversitesi, Sosyal Bilimler Enstitüsü’nde kabul edilen Siyasal Kriz ve Polis: I. Milliyetçi Cephe Hükümeti Polis Teşkilatı Üzerine Bir Mikro Çalışma adlı yayımlanmamış doktora tezinin bir bölümünden güncellenerek türetilmiştir.

** Yrd. Doç. Dr., İstanbul Ticaret Üniversitesi, İnsan ve Toplum Bilimleri Fakültesi, agenc@ticaret.edu.tr
} 


\begin{abstract}
It has been with the creation of national police forces all around the world that policing has raced into the political realm. At the same time the relationship between politics and the police has become apparent. However, the relationship between politics and the police has rarely been studied by political scientists interested in Turkish police studies. This work aims to fill this theoretical gap by analyzing the principal approaches to the relationship between politics and the police. In this respect, it aims to establish an analytical basis on how the relationship between politics and the police organization should be studied. The differences between these main approaches are due to the different definitions attributed to the concept of "police" by these same approaches. Approaches which define police as an institution mainly focus on the relationship between the police and political authority. According to these approaches, the police appear mainly as an instrument in the hands of political authority and act under the direct control of the government in power. So, the police organization does not achieve autonomy. Approaches which define police over policing and mainly as a function, in their turn, mostly focus on the influences of the activity of policing on political processes. Here policing has the ability to determine political processes. After the evaluation of these main approaches this study, in its turn, aims to integrate the concept of "police autonomy" in the analysis. For sure, police organizations remain related to the political power because they execute their function under the authority of governments. However, they also achieve some degree of institutional and personal autonomy since they construct their own identity and defend their own interests as a centralized and professional organization. However, this autonomy has its own limits. At this point, the concept of "relative autonomy" integrates into police research. The relative character of the police autonomy necessitates that empirical analysis based on socio-political contexts should be established for the observation of the relationship between politics and police.
\end{abstract}

Keywords: Police, Policing, Politics, Autonomy, Legitimacy

\title{
Giriş
}

Toplumsal hareketlere müdahalesi nedeniyle sokakta, hükümetlerin muhaliflere karşı duruşlarıyla yasalar nezdinde sıkça karşımıza çıkan polisin siyaset ile olan ilişkisi pratikte sıkça görünür olsa da polis ve polisliğe dair literatürde bu ilişkiye ilişkin analizlere sık rastlanmamaktadır. Bu doğrultuda, Türkiye'de $^{1}$ ve dünya genelinde ${ }^{2}$ polis-siyaset ilişkisi üzerine gerçekleştirilen çalışmaların azlığ 1 dikkat çekicidir. Bu durum, büyük ölçüde, polisin uzun süre siyaset ile olan ilişkisinin veri kabul edildiği ve bu nedenle de incelenmeye gerek görülmediği ön yargısı ile ilişkilidir. ${ }^{3}$ Diğer bir ifadeyle

1 Türkiyede YÖK tez veri tabanı üzerinden "polis" ve "siyaset" kelimelerini içerecek bir biçimde yapılan analiz sonucunda sadece 2015 tarihli bir adet çalışma olarak Seda Yıldız’ın “Türkiye’de Polis-Siyaset İlişkisine Dönemsel Bir Bakış" adlı doktora tezi ortaya çıkmaktadır.

2 Bayley (1983), polis çalışmalarında öncü kabul edilen The Police and Political Order in India adlı çalışmasında polis ve siyaset ilişkisi temelinde o güne kadar yapılan çalışmaların azlığından dem vurur. Benzer şekilde, JeanLouis Loubet del Bayle, La Police dans le système Politique (1981) adlı çalışmasında, Revue Française de Science Politique’in ortaya çıkış tarihi olan 1952 yılından 1971 yılına kadar geçen yirmi senelik sürede ilgili dergide "polis" sözcügünü içeren hiçbir yayına rastlanmadığını belirtmektedir. Bununla birlikte 1980 sonrası dönemde polis çalışmalarında bir canlanma olduğu gözlenmektedir. Bu doğrultuda polis çalışmalarına dair belli başlı eserler olarak nitelendirebileceğimiz çalışmalar burada not edilmelidir (Reiner, 1985; Neocleous, 2000; 2014; Newburn, 2008).

3 Polis-siyaset ilişkisi üzerine mevcut çalışmaların azlığı polis çalışmalarının uzun süre genel olarak zayıf kalmış olması ile de ilişkilidir. Ayrıca, polisin genel olarak gizli kalmak adına sarf ettiği çaba ile görevini en iyi şekilde yürütebilmesi ve faaliyetlerinin toplum tarafından sorgulanmaması için fazla tanınmama ve bilinmeme eğilimi de 
belirtmek gerekirse polis, siyasal iktidarın bir aracı olarak tahayyül edilmiş ve buna bağlı olarak ordu gibi ayrı ve özerk bir devlet kurumu olarak düşünülmemiştir.

Elinizdeki çalışma, Türkiye siyaset çalışmaları bağlamında polis-siyaset ilişkisine dair eksik olan teorik temele mütevazı bir katkı yapmak amacından yola çıkmıştır. Bu sayede ileride gerçekleştirilecek olgusal çalışmalara taban oluşturacak teorik temel için tartışma zemini ortaya konmak istenmektedir.

Polis-siyaset ilişkisine dair gerçekleştirilen teorik tartışmaları kabaca iki ana başlık altında incelemek mümkün görünmektedir. Bu iki başlıklı yapı polis-siyaset ilişkisine dair düşünen teorisyenlerin her şeyden önce polisi bir kurum ya da işlev olarak ele almalarıyla yakından ilişkilidir. Diğer bir deyişle, polisin bir devlet kurumu olarak tahayyülünden yola çıkan teoriler ile polisi polislik temelinde tanımlayan teorilerin polis-siyaset ilişkisine dair bakış açıları da polisi nasıl tanımladıklarıyla aynı doğrultuda şekillenmekte ve birbirlerinden ayrışmaktadır.

Buna göre ilk olarak işlev ve rolden yola çıkan teoriler (Bayley, 1985, Loubet del Bayle, 1981) polisin ne yaptığı ile ilgilendikleri müddetçe polis ve siyaset ilişkisini çift yönlü bir ilişkisellik olarak tahayyül ederler. $\mathrm{Bu}$ doğrultuda, polis siyaset tarafından etkilendiği ölçüde onu biçimlendirme ve yeniden dizayn etme kapasitesine sahiptir. Bir devlet kurumu olarak polisten yola çıan teoriler ise (Monjardet, 1996, Worrall, 2014) polisi kimin kontrol ettiği ya da kısaca kimin araçsallaştırdığı üzerinde yoğunlaştıkları ölçüde polis-hükümet ilişkisine eğilirler. Burada, polis-siyaset ilişkisi çok daha dar bir çerçeveden ve siyasal iktidarın polis üzerindeki denetim ve gözetimi temelinde tanımlanmaktadır. Her iki bakış açısının da kendine özgü dinamikleri olmakla birlikte, aynı zamanda, ikisi ilişkilidirler de.

Bu çalışma vesilesiyle yukarıda bahsi geçen polis-siyaset ilişkisine dair ana akım teorilere polisin özerkliği kavramsallaştırması temelinde bir katkı yapılmak suretiyle bu teoriler bir kez daha değerlendirilecektir. Polisin özerkliği kavramının analize dâhil edilmesinin gerekliliği her iki teorinin ortaya çıkardığı açmazların çözümünde bir anahtar işlevi görecektir.

$\mathrm{Bu}$ çalışma polis-siyaset ilişkisine dair başlıca teorik yaklaşımları eleştirel bir süzgeçten geçirmektedir. $\mathrm{Bu}$ vesileyle ilk olarak polisi bir kurum olarak ele alan araçsalcı bakış açısı incelenecek ardından polisi bir işlev olarak düşünen işlevselci teorinin değerlendirmesi yapılacaktır. Çalışmanın son ve üçüncü bölümü ise polisin özerkliği mevzusunu polis-siyaset ilişkisine dair tartışmaların arka planından çıkartıp merkezine yerleştirecektir.

\section{Bir Kurum Olarak Polis ve Polis-Siyaset İlişkisi}

Polislik ve polis teşkilatı arasında önemli bir ayrım bulunur. Buna göre en başından belirtilmesi gerekir ki modern devletin iç güvenlikten ve kamu düzeninden sorumlu ayrı bir kurumunun tekeline alınmadan çok evvel polislik işi tarihsel süreçte farklı aktörler tarafından yerine

yine polis-siyaset ilişkisinin uzun süre araştırma dışında kalmış olması ile ilgilidir (Loubet del Bayle, 1981, s.510). 
getirilmiştir. Dolaysıyla polisliğin geçmişi polis teşkilatına göre çok daha eskidir ve polislik işi modern devlet inşa sürecinden önce de var olmuştur. Diğer bir deyişle, polis teşkilatı bir kurum olarak modern devlet oluşum sürecinin son ve belirleyici aşaması olarak tanımlanırken polislik faaliyeti yüzyıllardır insanoğlunun güvenlik ve toplumsal uzlaşı ihtiyacının karşılanmasının bir gereği olarak farklı aktörler tarafından yerine getirilmiştir. Ordu da, modern polis teşkilatı kurulmadan evvel, polislik faaliyetini yerine getiren kurumsal aktörlerin başında yer almaktadır.

Polis teşkilatı; bürokratik, disiplinli ve suçun önlenmesi ile düzenin sağlanması işlerinde uzman (Bayley, 1985, Manning, 1977) bir modern devlet güvenlik aygıtına tekabül eden tanımını büyük ölçüde 19. yüzyılın ortalarına doğru almıştır. Bu dönemde gerçekleştirilen reform ile birlikte kurulan modern polis teşkilatı, modern devletin güvenlik aygıtında önemli bir dönüşüm meydana getirmiştir (Hülagü, 2011). 19. yüzyıl öncesinde polislik işi var olmakla birlikte bu işten sorumlu merkezi, bürokratik ve kurumsal bir yapının varlığından bahsedilemez. Diğer bir deyişle, modern polis teşkilatının kurulmasından önceki dönemde polislik modern öncesi devletlerin çeşitli aracı grup ve kişiler vasıtasıyla sağladıkları bir nevi dolaylı yönetime tekabül etmektedir (Ergut, 2012). Modern öncesi bu dönem boyunca polislik faaliyeti ve görevi esasen diğer toplumsal ilişkilerin birer uzantısı olarak ve ayrı bir kurumsallaşma belirtisi göstermeksizin sürdürülmüştür. $\mathrm{Bu}$ süreçte, bugün polis teşkilatı tarafından yürütülen birçok görev bizzat toplumun bireyleri tarafından ve kolektif sorumluluk anlayışıyla ait olunan toplumun üyesi olmanın bir gereği olarak gerçekleştirilmiştir.

1829 yllında gerçekleştirilen reform ile birlikte profesyonel ve merkezi bir devlet kurumu olarak örgütlenmiş polis teşkilatı ilk defa İngiltere’de vücut bulmuştur. 19. yüzyıl ile birlikte polisin rejimin istikrarına dair kamu düzeninden sorumlu ayrı bir devlet kurumu halini alması, polisi, bir kurum olarak siyasal otoriteye ve onun verdiği emirlere bağl kılmıştır (Monjardet, 1996). Bu bağımlılık polisi siyasal iktidar ile birlikte düşünme gereğini de ortaya çıkarmıştır.

Konuyla ilgili olarak Monjardet (1996, s.15-17), polisin tanımlanması çabasında çekiç metaforundan yararlanır. Çekiç, genel olarak çivi çakmaya yarar. Bu onun sık rastlanılan genel işlevidir. Ancak bunun yanında çekice otobüslerde ve metrolarda acil durumlarda camı kırmak suretiyle bir çıkış yaratmak amacıyla başvurulduğu da görülür. Benzer şekilde polis, demokratik bir toplumda sosyal hizmet temelinde tanımlanırken; otoriter bir rejimde muhalefetin baskılanması süreçleri üzerinden tanımlanabilir. Diğer bir deyişle, polisin üstlendiği görev ve işlevler çok çeşitlidir. Bu durum polisi işlevleri üzerinden tanımlamak yerine güç/şiddet kullanım araç/mekanizması olarak tanımlamayı daha geçerli kılar. Dolayısıyla çekiç "işlevinden ziyade" çekici kullanan kişinin niyeti temelinde tanımlanır. Özetle, burada çekici kullanan kişi siyasal otoritedir. Polisin işlevini belirleyen ve onu bu işlev temelinde kullanan da bizzat siyasal otoritenin kendisidir. Dolayısıyla kavramsal olarak odaklanılması gereken polislik değil de bizzat polis teşkilatıdır. Bu noktada, Monjardet (1996) araçsalcılık ilkesi (principe d'instrumentalité) kavramsallaştırmasını ortaya koyar. Bu kavramsallaştırmaya göre, siyasal otorite her zaman polisi araçsallaştırma imkânına sahip olarak nitelendirilir. İşte polisi teorize ederken analitik olarak 
yola çıkılması gereken başlangıç noktası da onun kurumsal olarak varlığı ve yine kurumsal olarak bağlı olduğu siyasal iktidar tarafından nasıl araçsallaştırılacağı ile ilişkilidir.

Weber'in (1968) meşhur tanımında devlet, meşru şiddet tekeline sahip olması temelinde tanımlanır. Bu tekel, devlete şiddet kullanacak kurum ve kişileri denetim altında tutma ayrıcalığı kazandırır. Bu nedenle siyasi kontrol, hukuki ilişki ve işe alım bakımından polis, siyasal iktidarın sürekli ve sıkı denetimi altındadır (Marenin, 1985). Polisin siyasal iktidara tabi olması ve onun sürekli denetimi altında yer alıyor olması üç kategori altında incelenebilir:

İlk aşamada polis-siyasal iktidar ilişkisi her şeyden önce atama ve görevlendirme ya da kısaca işe alımlarla ilgilidir ve bu durum hükümete polis teşkilatı üzerinde yoğun bir kontrol ve denetim oluşturma imkânı tanır. Polislik mesleğine alımlar ile ilgili hukuksal düzenlemeler devlet tarafından belirlenir ve uygulanır. Modern polis teşkilatının kurulmasını takip eden süreçte polislik mesleğine alımların nasıl yapıldığı, polisin merkezileşme ve profesyonelleşme süreçleriyle birlikte kurumun ve üyelerinin hükümetle ve dolayısıyla siyasetle olan ilişkilerinde de kilit bir rol oynamıştır (Mann, 1994). Siyasal iktidar ile polisi birbirine bağlayan bu süreçler polis memurunu amirine bağımlı hale getirmiştir.

Sonrasında polis teşkilatının genel yönelimi, teşkilatın konjonktürel olarak belirlenen öncelikleri, onun kullanacağı araçların tespiti vb. her zaman siyasaldır ve büyük ölçüde siyasal iktidar tarafından belirlenir. Bu doğrultuda kaynak ve bütçenin, hükümetler tarafından oluşturulması polis ve siyaset ilişkisini her daim canlı tutan bir ikincil kaynak olarak belirir.

Brewer ve diğerleri (1996) devletin kamu düzeninde dair stratejilerinin polis teşkilatına yönelik gerçekleştirilen yasa ve diğer hukuki düzenlemeler üzerinden çözümlenebileceğini savunur. Buna göre kamu düzenine dair baskıcı bir strateji izleyen siyasal iktidarlardan polisin bütçesine ağırlık vermesi beklenir. Öte yandan kamu düzenine dair uzlaşmacı bir strateji takip eden siyasal iktidarların polisi güçlendirmek yerine onu siyasal ve sosyal haklar lehine sınırlandırma amaçlı bir politika izledikleri görülür.

Son olarak, toplumsal düzene dair söylemi inşa eden siyasal aktörler bu söylemler aracılığıyla polise destek olabilmekte ve aynı şekilde ona karşı güvensizliği de toplum bünyesinde inşa etmek suretiyle meşruiyet kaybına yol açabilmektedirler (Jobard ve Maillard, 2015, s.62-64). Topluma dönük bir iç güvenlik kurumu olarak işleyen polisin varlığının temel bileşenlerinden biri olarak meşruiyet ilkesi siyasal iktidarlar tarafından güçlendirilebileceği gibi zedelenebilir de. Bu bağlamda, siyasal iktidarlar polis teşkilatının meşruiyetinden de sorumlu başlıca örgütlenmeler olarak belirirler.

İkinci aşamada siyasal iktidar ve polis, toplumsal muhalif hareketlerin polis tarafından gözetimi üzerinden de ilişkilendirilmelidir. Polis, kamu düzenini sağlamakla görevlidir. Polisin sürekliliğinden sorumlu olduğu düzen asla tarafsız bir düzen değildir; bilakis siyasal niteliktedir (Jobard ve Maillard, 2015). Dolayısıyla bu düzenin inşa süreçleri, siyasal iktidar tarafından denetim altında tutulmak istenir. Siyasal iktidarın kamu düzenini himaye altında tutma çabasında polis ve polislik kilit bir konuma sahiptir. 
Toplumsal hareket eylemleri karşısında uygulanacak olan polis gözetimi/denetimi (policing protest) açısından bir güvenlik gücünü göreve ya da konumuzu ilgilendiren kısım dâhilinde bir toplumsal harekete yönelik müdahaleye çağırmak yönetsel otoritelerin kararıdır (Fillieule ve Jobard, 1997, s.70-90). Ayrica, toplumsal hareketin polis tarafindan denetiminde uygulanacak olan polislik biçim ve faaliyetleri de doğrudan hükümetle, o hükümetin muhalif hareketler karşısındaki tavrı ve muhalif gösterileri algılayış biçimiyle de birebir ilgilidir. Kamu düzenine dair devlet stratejilerini belirleyen ve uygulayan da yine siyasal iktidardır. Muhalefetle uzlaşacak, muhalefeti kriminalize edecek ya da baskılayacak olan hükümet etmekle yetkili olan siyasal iktidardır (Brewer vd, 1996). Bu gerekçeyle polisin yetki ve kapasitesine yönelik çıkarılacak kanun ve çeşitli düzenlemeler nihayetinde siyasi otoriteler ile ilgilidir.

Polis ve siyasal iktidar arasındaki ilişkiyi yoğunlaştıran uygulama alanları yukarıdaki gibidir. Öte yandan, üçüncü olarak, bu uygulama alanlarında siyasal iktidarın etkisinin derecesi polis teşkilatının merkeziyet durumu ile belirlenir. Fransa ve mülki idare örgütlenme prosedürleri bakımından onu örnek alan Türkiye gibi ülkelerde polis teşkilatı sıkı sıkıya merkezileşmiş bir nitelik gösterir. ${ }^{4} \mathrm{ABD}$ deki polis teşkilatının parçalı (fragmented) bir yapıda örgütlenmiş olduğu söylenebilir. İngiltere gibi ülkelerde ise merkezi ve parçalı yapıların bir nevi karışımı olarak nitelendirebileceğimiz karmaşık bir örgütlenme söz konusudur. Burada, yerel ve merkezi güçlerin koordineli bir biçimde polislik faaliyetini yerine getirdikleri koordineli bir örgütlenme söz konusudur (Das ve Otwin, 2012, s.28).

Teşkilatın merkeziyet derecesinde vuku bulan söz konusu ayrışma tarihsel dinamiklerle belirlenmiştir. Polisin Fransa ve Avusturya başta olmak üzere kıta Avrupası̉nda ortaya çıkışı iktidarı elinde bulunduran hanedanların egemenliklerini kurma ve muhafaza etme süreçleriyle ilgilidir. Büyük Britanya örneğinde ise polis, hanedanlığın iktidarının devamlılı̆̆ için değil de hukuk düzeni içerisinde kralın düzen ve barışını uygulamak amacıyla ortaya çıkmıştır (Bayley, 1985, s. 204). Bu nedenle, Kita Avrupası (Fransa) örneğinde polis sistemi devlet merkezlidir. Hâlbuki İngiliz örneğinde polis toplum merkezli tahayyül edilmiş̧ir. Bu doğrultuda İngiltere’de polislik daha çok önlemek üzerinde temellendirilmişken Fransảnın başını çektiği Kıta Avrupası geleneğinde polislik denetlemek ile ilgilidir. Buradan hareketle İngiltere'de polisin oluşumu kapitalizm ve kentli işçi sınıfının varlığı ile açıklanırken Fransa’da polisin temel kaygısı toplumsalın düzenlenmesidir (Ergut, 2001). Dolayısıyla İngiltere örneğinde polis teşkilatının görev ve yetkileri çok daha sınırlı iken, Fransa örneğinde görüldüğü üzere polis teşkilatının görev alanı düzenin sağlanması gibi çok daha muğlak ve geniş kapsamlı bir içeriğe sahiptir.

Türkiye’nin bürokratik anlamda örnek aldığı Fransız polis sistemi İngiltere örneği ile tam bir tezat içerisinde bulunur. İçişleri Bakanlığı, Fransa’da, ülkenin her köşesindeki polis operasyonlarının yürütülmesinde yetkilidir. Aynı doğrultuda polislik de merkezi idarenin bir sorumluluğu olarak algılanmaktadır. Başkent Paris’te polislik işinden sorumlu bir vali bulunmaktadır. Prefet

4 Osmanlı’da polis örgütlenmesi kurulduğu yıl olan 1845 yılından başlayarak Fransız etkisinde kurumsallaşmıştır. Osmanlı polis teşkilatında Fransız etkisi, polise ve polisliğe dair kullanılan kelimelerden yönetmeliklere ve nihayetinde teşkilat şemalarına değin birçok alanda hissedilir (Lévy-Aksu, 2017, s.253; Gülmez, 1983). 
de Police olarak adlandırılan yetkili doğrudan İçişleri Bakanlığı’nın yetkisi ve denetimi altında bulunmaktadır (Bayley, 1975, s.334-335).

Polisin siyasal iktidarın denetimine maruz olma şartlarının incelenmesi, polis ve siyaset arasındaki ilişkinin çözümlenmesinde yeterli bir bakış açısı sağlamaz; polis-siyaset ilişkisinin sadece bir yönünü ortaya koyar. Polis-siyaset ilişkisi basitçe polisi hükümet ve siyasal iktidar bağımlı bir yapı olarak nitelendiren çalışmaların öngördüğünden çok daha karmaşık ve çetrefilli bir analizin konusunu oluşturmaktadır. Örneğin bu bakış açısı, farklı siyasal rejim tiplerinde siyasal iktidar ve polis arasındaki ilişkinin nasıl kurulduğu sorusuna cevap veremez. Halbuki siyasal rejimin niteliğine göre polis siyaset ilişkisi farklılıklar gösterir. Demokratik rejimlerde siyasal iktidar ve polis arasındaki ilişki hukukun üstünlüğü ilkesi (Linz ve Stepan, 1996a, 1996b) uyarınca polisin topluma hesap verebilirliği üzerinden inşa olurken totaliter ve otoriter rejimlerde bu ilişki az evvel incelediğimiz araçsalcı bakış açısını haklı çıkaracak biçimde büyük ölçüde siyasal iktidarın denetimi ve iradesinde gerçekleşir. Otoriter rejimlerde polislik hükümetin ya da rejimin çıkarlarını korumaya yönelik bir çeşit rejim polisliği olarak kendini gösterir.

Burada cevaplanması gereken önemli bir soru daha ortaya çıkmaktadır: Siyasal iktidarlar polisi neden denetim altında tutmak isterler? Ya da polisin de aktif olarak siyasal olana etkide bulunma çabası söz konusu mudur? Özetle polis-siyaset ilişkisinin çift örgülü bir yapısı olduğu iddia edilebilir mi? İşte bu soruların cevabı, polis-siyaset ilişkisinin çok daha genel ve ilişkisel bir bağlamda analizini gerekli kılar.

\section{Polislik İşlevi ve Polis-Siyaset İlişkisi}

Polis hem doğası ve devlet-toplum ilişkisinde işgal ettiği konum hem de işlevleri ve rolü bakımından siyaset ile yakından ilişkilidir. Kısaca polis, ne yaptığı, nasıl yaptığı, ne olduğu ve birbirlerine karşı ne yaptıkları temelinde ve farklı mecralarda siyasete etkilidir ve yine onun tarafindan etkilenmektedir.

Favre (2009, s.1241), polisin siyasetin tam da kalbinde yer aldığından bahseder. Reinere göre (1985; 2015), polis ve polislik işi özünde her zaman siyasaldır. Loubet del Bayle de (2006), polisin siyaset ve siyasal süreçler bağlamında işgal ettiği kritik konuma vurgu yapar. Ona göre, siyasal iktidarlar her zaman polisin rejimi ortadan kaldırmaya muktedir olduğu gerçeğini hesaba katmak ve ona göre davranmak zorundadırlar. Marenin’e göre (1985) polisin ve polisliğin siyasal doğası onun sürekli bir biçimde düzen inşa ediyor oluşundan ve bunu yaparken rıza ve zoru aynı potada eritme uğraşının sürekliliğinden kaynaklanır. Öte yandan polisin kamu düzeninin sağlanması ile ilgili ve görevli oluşu da polislik mesleğini her daim siyaset ile ilişkili kılar (Mann, 1994). Düzenin sağlanması ile görevli olan polis aynı düzenin bazıları tarafından adaletsiz ve eşitsiz görünmesi nedeniyle her zaman siyasal bir alanda konumlanır.

Polis ve siyaset ilişkisi bağlamında bugüne değin gerçekleştirilen en geniş kapsamlı teorik çalışmalardan birini kaleme alan Loubet del Bayle (1981) da ilişkiyi kavramsallaştırmadan 
önce ilk olarak bir polis tanımı ortaya koymaya çalışır. Polisi her şeyden önce bir işlev olarak tanımladıktan sonra toplumsal kontrolden sorumlu olarak nitelendirdiği polislik işlevinin özgün karakterinin fiziksel güç kullanma kapasitesine sahip oluşu olduğunu belirtir. Loubet del Bayle’in polis ve siyaset arasında kurduğu ilişki her şeyden önce polisin toplumsal düzeni sağlarken fiziksel güç kullanma kapasitesine sahip oluşu ile ilgilidir. Weber’in siyasal kolektivitenin varlığ 1 ve sürekliliğini mümkün kılan kuralların fiziksel güç tehdidi ve kullanımı ile sağlanıyor olması gerçekliğinden yola çıkan Loubet del Bayle, bu bağlamda, polis ve siyaset ilişkisini de polisin fiziksel güç kullanımı sayesinde yerine getirdiği düzen sağlayıcı işlevi ile ilişkili görür. Özetle polis, yerine getirdiği işlevler ve bu işlevlerin yerine getirilmesi için kullandığı fiziksel güç kullanma kapasitesi nedeniyle siyaset ile yakından ilişkilidir.

Loubet del Bayle (1981, s.510), polis-siyaset ilişkisinin rejimin tipi, siyasal sistemin gelişmişlik düzeyi veya merkezilik derecesi gibi çeşitli faktörlere göre değiştiği ve çeşitlendiği gerçeğini ortaya koyduktan sonra ilgili ilişkiye dair bir genel teori ortaya koyar. Buna göre Loubet del Bayle, ister işlevi açısından ele alsın isterse genel olarak sistem analizi bağlamında incelensin polisin her durumda siyaset ile olan ilişkisinin görünür ve somut olduğu tespitinde bulunur. Diğer bir deyişle, polis ve siyaset ilişkisi kaçınılmazdır.

Loubet del Bayle (1981), siyasetin Easton tarafından gerçekleştirilen sistemsel analizine referansla da polisi siyaset ile yakından ilişkili görür. Buna göre, siyasal merkezi çevreleyen toplumdan gelen talepler polis aracılığıyla merkeze iletilir. Polisin, karşı karşıya kaldığı ve çoğu zaman engellemekle yükümlü olduğu kalkışma, toplaşma gibi faaliyetler toplumsal taleplerin en açık dişa vurumu olarak doğrudan polis ve müdahalesi ile karşılaşırlar. Toplumdan devlete akan talepler polis tarafından iletilir. Aynı zamanda polis, sistem içerisindeki konumlanışı sayesinde toplumsal talepleri -açık veya kapalı - istihbarat ve bilgi olarak siyasal iktidara sunmakla yükümlü ve görevlidir. Demokratik rejimlerde polis bu rolünü diğer baskı grupları ile paylaşır. Öte yandan kapalı ve anti-demokratik sistemlerde polis, toplumsal taleplerin siyasal iktidar merkezine taşınmasında en önemli ve hatta tek aracı haline gelebilir. Bu, ilgili sistemlerde, polisi çok güçlü bir konuma yerleştirir.

İlk olarak taleplerin polis aracılığıyla regülasyonu görev ve işlevi, sistem içerisinde polise büyük bir iktidar ve ayrıcalık sağlar. Polis, bu işlevi sayesinde, bazı talepleri merkeze iletmeme ya da talepleri dönüştürerek merkeze sunma imkânına kavuşur. Öte yandan, toplumdan gelen taleplerin iletilmesi sürecini kontrol eden polis basin, sendikalar ve siyasal partilerin bu taleplerin iletilmesi sürecindeki rol ve etkilerini kısıtlama yoluna gidebilir. Bu durum, polise, taleplerin siyasal merkeze iletilmesi hususunda egemenlik sağlar. Sansür ve gözetim yoluyla diğer talep iletici kurum ve aktörleri engelleyebilen polis, iktidarın tek bilgi kaynağı haline gelebilir. Bu ise, Loubet del Bayle’in en başından hatırlattığı polisin fiziksel şiddet tekelini kullanabilme kapasitesine sahip oluşu ile ilgilidir.

İkinci olarak, polis sistemin çıtılarını ya da diğer bir deyişle siyasal merkezin aldığı kararların toplumsal sistemde uygulanmasını sağlamakla yükümlüdür. Bu, polisin siyaset ile olan ilişkisinin 
en görünür özelliğini oluşturur. Polis, siyasal sistemin aldığı kararları uygularken aslında fiziksel şiddete başvurma tehdidi aracılığıyla toplumu organize eder. Polis, bu sayede, siyasal sistemin çıktılarının toplum nezdinde uygulanması sürecinde genişçe bir hareket serbestisinden yararlanır. Sokakta polis ile karşılaşan toplum polisin silüetinden yansıyan devlet iktidarı ile karşı karşıya gelir. Denilebilir ki; devlet polis üzerinden topluma ulaşır.

Polis çalışmalarının Anglosakson literatürdeki en önemli isimlerinden David Bayley (1985) polisin siyaset alanındaki rolünü ayrıntılı bir biçimde tanımlamaya çalışır. Buna göre polis, çeşitli vesile ve yöntemlerle siyasete müdahalede bulunur. Ancak, Bayley, ilgili vesile ve yöntemlerin detayına girmeden evvel önemli bir tespit ve uyarıda bulunur.

Bayley’e göre (1985, s.189), polisin siyasal iktidar ya da hükümet ile eşitlenmesi ve onun üzerinden tanımlanması analiz düzeyinde bazı sorunlar ortaya çıkarır. Eğer polis faaliyetinin niteliği ve karakterini siyasal rejimin doğasını tanımlamakta kullanırsak ortaya düşünsel anlamda bir çıkmaz çıkmaktadır. Baskıcı polis faaliyeti rejimin demokratik olmadığını tanımlamak için kullanılırsa, rejimin polis faaliyetini belirleyebileceği gerçeği görmezden gelinebilir. Rejimin doğasının belirleyeni olarak sunulan polis faaliyeti polisin siyasal olarak oynadığı rolün siyasal rejim üzerinden tanımlanmasını imkânsız hale getirir. Burada analiz büyük bir açmaza girer.

Polisin baskıcı faaliyeti, bazı durumlarda, rejimin demokratik karakterine rağmen polisin iradesinde devreye girebilir. Tam tersi biçimde, baskıcı bir rejimde demokratik ve toplum yanlısı bir polis davranışı ya da faaliyeti ortaya çıkabilir. Bazı istisnai durumlarda ise polis, muhalefetin devrimci kalkışmalarına müdahalede bulunmayarak ya da görmezden gelerek rejim değişikliğine dahi üstü örtülü bir destekte bulunabilir. Bu durum polis-siyaset ilişkisini rejimin tipi ya da siyasal iktidarın karakteri ile özdeşleştirmeye dönük indirgeyici bakış açısını işlevsiz ya da kısıtlı kılar.

Bu nedenle, Bayley’e göre, polis-siyaset ilişkisini rejim ve hükümet temelinde açılayan sınırlı yaklaşımlar yerine polisin, farklı rejim tiplerinde ve çeşitli siyasal konjonktürlerde, ortak olan siyasete müdahale yöntem ve biçimlerine bakmak daha ufuk açıcı bir analizin yolunu açmaktadır.

Hülagü (2012, s.141), Bayley’nin (1985, s.197) polis-siyaset ilişkisine dair geniş ve detaylı teorisini ana hatları ile özetler: Bayley’e göre polis bir kurum olarak siyasete altı ana başlık altında müdahalede bulunur ve tüm bu müdahale biçimleri siyaseti polisin müdahalesine açık hale getirir. Buna göre;

- Polis tutuklama, gözaltı gibi yöntemler aracıllğıyla kimin siyaset yapabileceğini ya da kimin siyasetle uğraşabileceğini belirler. Bu tür pratikler özellikle siyasal muhaliflere karşı kullanilır.

- Polise çeşitli siyasi süreçlerde düzenleyici rol verilir, seçim güvenliğinin polis tarafından sağlanıyor olması siyasi süreçlerin polis tarafından düzenleniyor olmasının önemli ve somut örneklerinden biri olarak not edilebilir. 
- Hükümete yönelik şiddetli muhalefet, kalkışma gibi eylemlerin ya da halk hareketlerinin rejim değişikliği ya da devrim ile sonuçlanıp sonuçlanmayacağ bir rol oynar. Özetle, bu gibi toplumsal muhalefet eylemlerinde polisin hangi tarafta yer alacağı rejimin geleceğini belirler. Örneğin Fransız Devrimi’nin şafağında polis, şehirdeki kalkışma ve ayaklanmalara hiçbir direniş göstermeyerek devrimi kolaylaştırmıştır. Benzer şekilde İtalya'da Carabinieri Mussolini’nin Squadrista'sı ${ }^{5}$ karşısında direniş göstermemiş, sendeleyen hükümetten yana olmak yerine sempati duyduğu Mussolini’ye direnmeyerek iktidarını kolaylaştırmıştır.

- İstihbarat ve provokasyon faaliyetlerini yürüten ve yöneten polis siyasete de her daim müdahildir. Gizli veya yüksek ${ }^{6}$ polislik olarak adlandıracağımız polislik biçimi siyasal sürecin farklı aşamalarını denetleme ve kontrol altında tutma imkânı sağlar.

- Polisler kimi zaman farklı örgütlenmeler aracılığıly aktif olarak siyasete katılır ve yasa yapım süreçlerinde yer alırlar. ${ }^{7}$ Bazı ülkelerde ise polis iktidarı resmi olarak hükümetin çeşitli mercilerinde temsil imkânı bulabilir. Örneğin SSCB'de KGB Politburoda temsil hakkına sahiptir.

- Son olarak kanun uygulayıcısı olan ve bunları uygularken geniş bir takdir yetkisinden yararlanan da polistir, dolayısıyla merkezde alınan siyasal kararların uygulayıcısı olan polisler uygulamada genişçe bir özerklikten yararlanırlar. Bu da siyasal süreçleri belirleyici bir iradeye işaret eder.

Bayley (1985, s.197) yukarıda sıralanan polisin siyasete müdahalesine dair yöntemleri "doğrudan” yöntemler olarak nitelendirir. Diğer bir ifadeyle, yukarıdaki yöntemler aracılığıyla polis, belirlediği siyasal saiklerle bilinçli olarak ve doğrudan siyasete müdahil olur ve siyasal süreçlere iradi bir biçimde etki eder.

Bu noktada, polis-siyaset ilişkisine polislik ve faaliyet temelinde bakan yaklaşımların polisin de siyasete etkide bulunabileceğini çok daha fazla vurguladıkları ortaya çıkmaktadır. Monjardet önderliğinde gelişen kurumsalcı literatürde polis daha çok siyasal iktidarın denetiminde tanımlanırken Loubet del Bayle ve Bayley'nin teorilerinde polis, siyasete aktif bir özne olarak katılır ve siyasal süreçler tarafından etkilendiği gibi o süreçleri bizzat etkiler de.

Buraya kadar polis-siyaset ilişkisine dair ortaya konan teori ve açıklamaları ana hatlarıyla ve çok genel olarak özetlemeye çalışıldı. Tüm bu farklı yaklaşımların üzerinde ortaklığa vardıkları temel prensip polis ve siyaset arasındaki ilişkinin yadsınamaz olduğu gerçeğidir. Ayrıldıkları nokta ise polis-siyaset ilişkisinin kaynaklarıdır.

5 İtalya’da Mussoli’nin Ulusal Faşist Parti’sinin paramiliter kanadı giydikleri siyah gömlekler nedeniyle anglo sakson literatürde Blackshirts olarak anılmaktadırlar.

6 Yüksek polislik ifadesi Brodeur'e aittir. Buna göre Brodeur (1983) polisliği analitik olarak iki sınıfa ayırmak suretiyle inceler. Yüksek -haute - ve alçak -basse - polislik.

7 Örneğin 1990’lı yıllarda Türkiye’de Ceza Muhakemesi Kanunu’nda yapılacak değişikliklere yönelik artan polis tepkisi zamanla aktif muhalif gösterilere dönüşmüștür. Bkz. (Bora, 1994). 
Loubet del Bayle ve Bayley ağırlıklı olarak polisin işlevleri ve rolü üzerinde dururlar. Bu bakış açısı polis-siyaset ilişkisini polis-hükümet ilişkisine indirgeyen yaklaşımın bir adım ötesine geçer ve polisi siyasal süreçlere etki eden aktif bir politik aktör rolüne soyundurur. Diğer bir deyișe, polis de bizzat siyaset yapıcı bir özneye dönüşür. Siyasal süreçlerde edilgen değil de aktif bir polis karşımıza çıkar. Halbuki Monjardet (1996) polisi, bir devlet kurumu olarak gördüğümüz takdirde, onun da tıpkı diğer devlet kurumları gibi siyasal iktidar tarafından üzerinde etkide bulunma ve araçsallaştırma eğilimlerine yapısal olarak boyun eğeceği tespitinden yola çıkar. Siyasal iktidarlar da devletin güvenlik aygıtını her daim kontrol ve denetim altında tutmak isterler. Diğer bir deyişle; siyasal iktidar farklı yöntem, süreç ve derecelerde polis üzerinde denetim ve kontrol kurma mücadelesi yürütür. Polisin kamu güvenliğinin sağlanmasında teknik ve göreli bir özerkliğe sahip olduğu ilkesel olarak kabul edilse de gerçekte siyasi otoriteler ve özellikle hükümetler her zaman polislik süreçlerine müdahildir. Bu daha çok polis-siyaset ilişkisini polishükümet ilişkisi ile sınırlı tutan bir yaklaşıma tekabül eder ve polisin siyasete müdahalelerini ve polisin siyaset yapıcı niteliğini görmezden gelir.

Her iki yaklaşımda da öne çıkan gerçek şudur ki ister sistem içindeki rolü ister işlevleri isterse prosedürel olarak hükümet denetimi altında bir kurumsal yapı olarak konumlanışı nedeniyle olsun polis her zaman siyasete ve siyasal süreçlere müdahildir. Öte yandan, siyasal iktidarın polisi denetim altında tutma çabası ile kamu düzenini sağlamakla görevli olan polisin siyaset ile kesişen yolları, nihayetinde, polisi toptan siyasal iktidar bağımlı bir araç haline getirmez. Tersine, polisin örgütsel yapısı ile mesleki kimliği, ona genişçe bir özerk alan açar. İşte bu noktada polisin hem kurumsal olarak sahip olduğu hem de bireysel olarak sahada görev yaparken yararlandığ özerklik kavramı analize dâhil edilmelidir.

\section{Polisin Özerkliği ve Polis-Siyaset İlişkisi}

Polis-siyaset ilişkisini anlamak için polisi tanımlamaktan çok polisin de tıpkı diğer aktörler gibi göreli ama belirli bir özerkliğe sahip olduğunu kabul ederek yola koyulmak analiz düzeyinde çok daha makul görünmektedir. Bora’nın (1992) ifade ettiği üzere polis adı konmamış bir özerklikten yararlanır. ${ }^{8}$ İşte bu özerklik onun siyaset ile olan ilişkisine dair genel-geçer teoriler oluşturma çabasını anlamsız kılar. Bunun yerine, polis-siyaset ilişkisi tarihsel bağlamda polisin evrilen ve dönüşen özerkliği ile birlikte düşünülmelidir.

Polis teşkilatı hiyerarşik yapısı, katı kuralları, emir-komuta zincirinin önemi ve yine görevlerin katı tanımlamaları ile diğer kamu kurumlarından ayrılan örgütlenme olarak belirir. Polisin bir diğer güvenlik aygıtı olan orduyu belirli yönlerden taklit etmek suretiyle örgütlendiği ve kurumsallaştığı bu noktada not düşülmelidir. Bu anlamıyla polis, hiyerarşik ve merkezi bir yapılanmaya işaret eder ve emirlerin uygulanmasının takibini ve kontrolünü merkezden

8 Bora (1992) polisin Türkiye’de her zaman görece özerk bir konuma sahip olduğundan bahseder. Ancak ona göre bu özerklik "adı konmayan” bir özerkliktir çünkü polisin özerkliği ordunun özerkliğinde olduğu gibi ideolojik ve yapısal boyutlarıyla tartışılma imkânı bulamamıştır. Hükümetin tümden kontrolü ve himayesinde konumlandırılan polisin ara ara ortaya tüm gerçekliğiyle çıkan özerkliği detaylı bir analizin konusunu henüz oluşturmamıştır. 
gerçekleştirir. Anglosaksonların emir-komuta (command and control) biçiminde tarif ettikleri bu piramidal yapı, büyük ölçüde askeri örgütlenme örnek alınarak inşa edilmiştir. Ancak polis örgütlenmesinin görünen hiyerarşik ve piramidal yapısı ile gerçekte işleyişi arasında önemli farklar bulunur. "Polis güçleri, hükümetler tarafından siyasal süreçlere müdahale aracı olarak kullanılabilirse de, bu, onların basit birer kukla oldukları anlamına gelmez. Bürokratik yapısı bir kez konsolide olduktan sonra polis, hükümetlerden göreli olarak özerk bir konuma geçebilir” (Ergut, 2001, s.69).

Della Porta ve Fillieule (2004, s.218), policing of protest kavramı üzerinden polisliği yeniden sorguladıkları ve tartışmaya açtıkları çalışmalarında basitçe şu soruyu sorarlar: "Polisi, sadece, devletin silahlı kolu olarak görmek ya da nitelendirmek mümkün müdür?” Diğer bir deyişle polis, bir güvenlik aygıtı olarak, hükümetten aldığı emirleri doğrudan ve sorgulamadan uygulayan bir iktidarbağımlı yapı mıdır? Polisi, sadece, siyasal iktidarın elinde bir araç olarak nitelendirmek yeterli bir bakış açısı mıdır? Yoksa örgütün bir nevi (göreli) özerkliğinden bahsetmemiz mümkün müdür?

Della Porta ve Fillieule’in yukarıda değindiğimiz sorusuna, polisin özerkliği sorunsalı bağlamında, bir soru daha eklemek mümkün görünmektedir. Polis memuru, sahada görev yaparken tümüyle hukuk ile sınırlı mıdır? Yoksa polisin suçun kovuşturulması ve düzenin sağlanması faaliyetlerini yürütürken sahada yararlandığı bir özerk manevra alanından bahsedilebilir mi?

Favre (2009, s.1238), polis sosyolojisinin en önemli öğretilerinden birinin polisin özerkliğinin ortaya çıkarılması olduğunu belirtir. Polisin özerkliği sorunsalı hem polisin bir kurum olarak siyaset ile olan ilişkisi hem de polis memurunun yetki alanı ve manevra kabiliyeti bakımından büyük önem taşır ve tam da bu nedenle iki aşamalı olarak ele alınmalıdır (Jobard, 2013). ${ }^{9} \mathrm{Bu}$ bağlamda, polis aygıtı hiyerarşik olarak bağlı bulunduğu siyasal otorite karşısında; polis memurları ise yine hiyerarşik olarak kendi üst mevkilerindeki yöneticiler karşısında belirli derecede ama geniş bir özerk hareket alanına sahip bulunmaktadır.

İlk olarak, polis özerkliğinden kastedilen mikro seviye olarak adlandırabileceğimiz polis memurunun görevi sırasında sahada karar alırken yararlandığı özerkliktir. Özerkliğin bu mikro boyutu polis çalışmaları literatüründe kısaca polisin takdir yetkisi olarak adlandırılır. Aslında,

9 Polis çalışmaları literatürü polis özerkliği sorunsalı ekseninde kıta Avrupa geleneği ile İngiltere merkezli Anglosakson gelenek arasında farklılık olduğu yolunda hemfikirdir. Buna göre İngiltere geleneği polisin sahada yararlandığı özerkliğe vurgu yapar ve kanunun uygulanması süreçlerini polis memurunun sorumluluğunda nitelendirir. Kıta Avrupası geleneği ise polisi ağırlıklı olarak hükümetin silahlı kolu olarak görme eğilimindedir. Jobard (2013) polisin özerkliği sorunsalı ekseninde coğrafi olarak yapılan bu ayrımın az veya çok kabul edilebileceğini belirtir. Ancak, ona göre, bu gelenek farklılıkları polisin özerkliği sorunsalına dair çok keskin ayrımların ortaya çıması sonucunu doğurmamıştır. Öyle ki, her ülkede derecesi değişmekle birlikte polis, personel politikalarından, atamalardan, ödüllendirmelerden ve genel polis politikalarının belirlenmesinden sorumlu olan siyasal otoriteye karşı sorumludur ve onların denetimi altında bulunur. Diğer bir deyişle, polisin kurumsal özerkliği bu gerekçeler ile kısıtlanır. Öte yandan, yine her ülkede, derecesi değişmekle birlikte her polis teşkilatı örgütlenme olarak kendi kültür ve kolektif kimliğini oluşturur. Bu sonuncusu, polisin kurumsal özerkliğini artırıcı bir etkide bulunur. Tüm bürokratik kurumlar sahip oldukları özgün tecrübe ve bilgi birikimi neticesinde kendi politik merkezlerinden bağımsızlaşma yönünde bir eğilime sahip olurlar (Deflem, 2004, s.77). Dolayısıla polis kurumsal olarak siyasal iktidara sorumlu olması bir yandan, kendi kimliğine ve dolayısıyla çıkarlarına sahip bir örgütlenme oluşturması bakımından, diğer yandan, göreli bir özerkliğe sahiptir. 
Loubet del Bayle ve Bayley’nin polisin siyasete etkilerine yaptıkları vurgu büyük ölçüde polisin takdir yetkisi ile ilişkilidir. Bunun dışında, ikinci olarak, polisin bir kurum olarak yararlandığ makro seviye olarak adlandırdığımız özerklikten de ayrıca bahsedilmesi gerekir. Bu sonuncusu polisin bir kurumsal yapı olarak siyasal otorite ile ilişkisi bağlamında ve onun karşısında yararlandığ

Polisi ve polis teşkilatını basitçe hükümetin silahlı kolu olarak nitelendirmek ve onu bağlı bulunduğu siyasal iktidara bağımlı bir monolitik yapı olarak nitelendirmek tarihin hiçbir aşamasında gerçekleşmemiş ve birçok iktidarın hayali olarak kalmış basit ve karşıllğ 1 olmayan bir önerme olarak nitelendirilebilir. Ergut (2011), konuyla ilgili olarak Pinochet dönemi Şili’sini örnek gösterir. İlgili diktatörlük yönetimi altında dahi Pinochet bir taraftan insan hakları savunucularını zindanlara atıp onları işkenceyle cezalandırırken öbür taraftan aynı insan hakları savunucularının kendi polis aygıtı hakkında birikim ve fikirlerini ya da diğer bir deyişle istihbaratını toplamaktadır. Pinochet'nin bundaki amacı basittir: Kendi polisi üzerinde denetim sağlayabilmek. "Zira her polis örgütü gibi Şili polisi de hangi bilgileri diktatörle paylaşacağına hangilerinin örgüt içinde kalacağına karar vermeye muktedirdi. Polis, bilginin iktidarda olduğunu Foucault'dan çok önce biliyordu."

Yukarıda Ergut tarafından sunulan örnekten de kolaylıkla fark edileceği üzere her hükümetin polisi denetim altında tutmak istemesi aşikâr olmakla birlikte hükümetin polis teşkilatı üzerindeki denetim kurma talep ve stratejisi, polis tarafından çok farklı direniş, tepki ve strateji ile karşılaşmaktadır. Çünkü polislerin hükümetin üzerindeki denetimini aşmak üzere çalıştırabileceği birçok özgün mekanizması ve taktiği vardır. Burada önemli olan polisin her iktidar yapısında derecesi değişmekle birlikte her daim var olan özerkliğidir.

Göreli özerklik, polisin yürüttüğü faaliyetlerde derecesi değișen bir özerklik/bağımsızlıktan yararlandığı gerçeğine işaret eder. Bazen hükümete destek bazen ona karşıt, bazen başlı başına bir politik aktör, bazen işçi hareketiyle ittifak halinde beliren polisler bu anlamda devlet ve toplum arasında dinamik bir ilişkisellik ve görece bir özerklik çerçevesinde analiz edilebilir.

Söz konusu özerklik ile onun göreli karakteri polise dair başlıca iki nitelikten kaynaklanır: Bunlardan birincisi polisin devletin kurumsal bir örgütsel yapısı olması itibariyle profesyonelleşme ve bürokratikleşme süreçleri sonrasında kendine has bir örgütsel yapı ve polislik kimliği geliştirmesiyle ilgilidir. Bu durum aslında profesyonelleşmiş tüm meslek grupları için söylenebilir. Profesyonelleşen gruplar, belirli bir süre sonra kendi çıkar ve kültürlerine sahip özerk oluşumlar haline gelirler. Bu özerklik yardımıyla, meslek grupları üçüncü kişi ve kurumlar tarafından araçsallaştırılma eğilim ve stratejilerine direniş gösterirler. Polis de bu bakımdan istisna oluşturmaz.

İkinci olarak polis çift yönlü karakteri nedeniyle, devlet ve toplum arasında salınan müphem ilişkisel bir alana tekabül ettiğinden dolayı sürekli bir meşruiyet arayışında olur. Meşruiyet mekanizması ise sabit bir nitelik ya da karakteristik olmaktan öte toplumsal ilişkiye tekabül eder (Jobard, 2008). İlişkisel olarak kazanılır ve kaybedilir. Polis hem bürokratik bir örgütlenme hem 
de toplumla devlet arasında bulunan stratejik konumu itibariyle meşruiyet arayışında bir kurum olarak göreli bir özerklikten yararlanır. Meşruiyet mekanizması onu topluma bağlar ve toplumla olan bu dinamik ilişkisi, polisi tümden siyasal iktidar bağımlı bir yapı olmaktan kurtarır. Devlet ve toplum arasındaki gidip gelmeler ve ikisine karşı üstlenilen sorumluluklar polise bu ilişkisellikte hareket kabiliyeti kazanma imkânı tanır.

Öte yandan sıkça vurgulandığı üzere polisin özerkliği görelidir. Diğer bir deyişle, farklı tarihsel ve toplumsal bağlamlara göre yoğunluğu artar ve azalır. Çok genel bir sınıflandırma yapmak gerekirse polisin özerkliğinin şu şartlar altında değiştiğinden bahsedebiliriz (Marenin, 1985, s. 118):

- Kalkışma, kriz zamanlarında polisin özerkliği büyük ölçüde artar.

- Toplumsal kontrol mekanizması olarak fiziksel güç kullanımının artması bu gücün meşru kullanıcısı olarak polise ayrıca bir özerklik verir.

- Diğer devlet yapılarının kurumsallaşmadığı zamanlarda polisin özerkliği yine görece olarak artar.

- Son olarak devletin meşruiyetinin azaldığı ya da düşüşe geçtiği dönemlerde polisin özerkliğinin artabileceğinden bahsedilebilir.

Polisin özerkliğinin göreli karakteri, polis-siyaset ilişkisi başta olmak üzere polise dair çeşitli konularda yapılacak araştırmaları ve olgusal çalışmaları belirli bir tarihsel ve toplumsal bağlama yerleştirme gereğini zorunlu kılar. Bu sayede polisin siyasal ve toplumsal şartlarla evrilen özerkliğinin azalan veya artan karakteri dinamik bir bakış açısı geliştirmeyi gerekli kılar. Polissiyaset ilişkisi de, tüm bu gerekçelerle, polisi kurumsal ya da polisliği işlevsel olarak ele alan genel geçer yaklaşımlar yerine polisin özerkliğini de hesaba katan tarihsel ve toplumsal bağlamlarda gözlemlenmek suretiyle incelenmelidir.

\section{Sonuç}

Sonuç olarak polis, ne hiyerarşik, merkezi bir örgütlenme olarak hükümetin bir kolu olarak görev yapar ne de başlı başına otonom kararlar alabilen özerk bir örgütlenme olarak belirir. Polisin siyaset ile olan ilişkisi de her şeyden önce bu tespitten yola çıkılarak düşünülmelidir.

İster doğası gereği olsun, ister işlevleri ve rolü gerekçesiyle olsun isterse bir kurumsal yapı olarak devlet ve toplum ilişkisi temelinde konumlanışı ile ilgili olsun polis-siyaset ilişkisi karmaşık bir ilişkisellikle evrilir. Polis-siyaset ilişkisine dair ortaya konan yaklaşımların farklılığı, büyük ölçüde, polisin ne olduğuna dair ortaya konan farklı tanımlamalardan kaynaklanır. Diğer bir deyişle, polisin nasıl ve ne temelinde tanımlandığı sorunsalı onun siyaset ile ilişkisine dair ortaya konan yaklaşım ve kavramsallaştırmaları da belirler. 
Aktörler arası ağlar ve yine bunlar arasında gelişen birlik benzeri örgütlenmeler polisin otonomi ve bağımlılık hallerinin niteliğini ve dereceleri ile siyaset ile olan ilişkisini de belirler (Jobard ve Maillard, 2015, s.78). Polisin bir modern devlet kurumu olarak siyasal iktidar denetiminde görev yapıyor olması bir yana polislik işlevinin gereği olarak polisin hem siyasete etki eden hem de onun tarafından etkilenen çift örgülü ilişkisi öbür yana polisi tüm bu teorik yaklaşımların birleşiminde bir yerde düşünmeyi gerekli kılar. Bu noktada ise belirleyici olan polisin özerkliği kavramsallaştırmasıdır. Polisin hem bürokratik, merkezi ve profesyonel bir devlet kurumu olarak sahip olduğu özerklik hem de polisin polislik işinin gereği olarak sahada yararlandığı ve ona ciddi bir hareket alanı açan mikro düzeydeki özerklik olarak takdir yetkisi polisin kurum, polisliğin işlev olarak siyaset ile olan ilişkilerinin belirlenmesinde kilit önemdedir. Dolayısıyla, polis-siyaset arasındaki ilişkinin hakiki bir değerlendirmesi ancak tarihsel bağlama yerleștirilen olgusal çalışmalar üzerinden layıkıyla incelenebilir. Polisin artan-azalan özerkliği ile bu özerkliğin polisin genel olarak siyaset ve özel olarak siyasal iktidar ile olan ilişkilerindeki yansımaları ancak söz konusu tarihsel bağlamlarda anlam kazanır. 


\section{Kaynakça}

Bayley, D. (1975). “The Police and Political Development in Europe”, ed. C. Tilly. The Formation of National States in Western Europe. Princeton: Princeton University Press.

Bayley, D. (1983). “The Police and Political Order in India”. Asian Survey. 23(4), 484-496.

Bayley, D. (1985). Patterns of Policing. New Brunswick: Rutgers University Press.

Bora, T. (1992). "Terör, Devlet ve Türk Sağı", Birikim Dergisi. 37, 48-57.

Bora, T. (1994). "Devletin Polisi, Polisin Devleti”, Birikim Dergisi. 57-58.

Brewer, John D., R. Wilford, A. Guelke, I. Hume, E. Moxon-Browne. (1996). The Police, Public Order and the State. New York: St. Martin's Press Inc.

Brodeur, J-P. (1983). "High Policing and Low Policing: Remarks About the Policing of Political Activities". Social Problems. 30, 507-520.

Das, D., O. Marenin. (2012). Challenges of Policing Democracies: A World Perspective. Routledge.

Deflem, M. (2004). "Social Control and the Policing of Terrorism: Foundations for a Sociology of Counterrorism. The American Sociologist. 35(2), 75-92.

Della Porta, D., O. Fillieule. (2004). Policing Social Protest, ed. D. A. Snow, S. A. Soule, H. Kriesi. The Blackwell Companion To Social Movement. Oxford: Blackwell Publishers, 217-241.

Ergut, F. (2001). “Polis Çalışmaları İçin Kavramsal Bir Çerçeve”. Amme İdaresi Dergisi. 34 (1), 59-78.

Ergut, F. (2011). "Ergenekon, Polis ve Siyasal İktidar". Demokrat Haber. 13 Mart.

Ergut, F. (2012). Modern Devlet ve Polis Osmanlidan Cumhuriyet’e Toplumsal Denetimin Diyalektiği. 2. Bsk. İstanbul: İletişim.

Favre, P. (2009). Quand la Police Fabrique l'Ordre Social Un en deça des Politiques Publiques de la Police? Revue Française de Science Politique. 59, 1231-1248.

Fillieule, O., F. Jabord. (1997). The Policing of Protest in France: Towards a Model of Protest Policing, ed. D Della Porta, H Reiter. The Policing of Protest in Western Democracies. Minneapolis ve Londra: University of Minnesota Press, 70-90.

Gülmez, M. (1983). “Polis Örgütünün İlk Kuruluş Belgesi ve Kaynağı”. Amme İdaresi Dergisi. 16(4), 3-15.

Hülagü, F. (2011). "Restoring Class Power Over the Police: The Role of the International in Neoliberal Police Reform in Turkey”. Yayınlanmamış Doktora Tezi. Ankara: Orta Doğu Teknik Üniversitesi Sosyal Bilimler Enstitsü.

Hülagü, F. (2012). Kuruluştan 1980'lere Türkiye'de Polis Aygitına Uluslararasılaşma Süreçleri Üzerinden Bakmak. Memleket Siyaset Yönetim. 7(17), 137-177.

İnanıc1, H. (2012). “Türkiye’de Polis, İktidar ve İnsan Hakları”. Birikim. 273, 14-23.

Jobard, F. (2008). "Lautorité de la Police". Vacarme. 8(43), http://www.vacarme.org/article1557.html [13.12.2015]

Jobard, F. (2013). "Police Autonomy". The Wiley Blackwell Encyclopedia of Political Science. Ed. B. Badie, D. Berg-Schlosser, L. Morlino. Los Angeles, Califf: Sage Publications: 1876-1879.

Jobard, F., J. de Maillard. (2015). Sociologie de la Police: Politiques, Organisations, Réformes. Paris: A. Colin. Lévy-Aksu, N. (2017). Osmanl İstanbulu’nda Asayiş 1879-1909. çev. Serra Akyüz. İletişim: İstanbul.

Linz, J., A. Stepan. (1996a). “Toward Consolidated Democracies”. Journal of Democracy. 7(2), 14-33.

Linz, J., A.Stepan. (1996b). Problems of Democratic Transition and Consolidation. The John Hopkins University Press.

Loubet del Bayle, J-L. (1981). "La police dans le Système Politique", Revue Française de Science Politique. 31(3), 509-534. 
Mann, P. (1994). “Pouvoir Politique et Maintien de l'Ordre Portée et Limites d’un Débat". Revue Française de Sociologie. 35(3), 435-455.

Manning, P K. (1977). Police Work: The Social Organization of Policing. Cambridge, MA: MIT Press.

Marenin, O. (1985). "Police Performance and State Rule: Control and Autonomy in the Exercise of Coercion". Comparative Politics. 18(1), 101-122.

Monjardet, D. (1996). Ce que Fait la Police Sociologie de la Force Publique, Paris: Editions de la découverte.

Neocleous, M. (2000). Fabrication of Social Order: A Critical Theory of Police Power, Sterling: Pluto Press

Neocleous, M. (2014). Savaş Erki Polis Erki. Çev. Beyza Sümer Aydaş. Ankara: Notabene Yayınları

Newburn, T. (2008). Handbook Of Policing. Willian Publishing.

Reiner, R. (1985). The Politics of the Police. Brighton: Harvester.

Reiner, R., D. O'Connor (2015). "Politics and Policing: the Terrible Twins", ed. J. Fleming, Police Leadership: Rising to the Top. Oxford UK: Oxford University Press: 42-70.

Weber, M. (1968). Economy and Society, Volumes I, II, III. çev. A. M. Handerson ve T. Parson. New York: Bedminster Press.

Worrall, J L. (2014). “The Politics of Policing”, ed. M. D. Reisig, R. J. Kane. The Oxford Handbook of Police and Policing. Oxford University Press. 
